\title{
Investing In Accounting: A Call For Professional Involvement In Higher Education
}

Chun-Chia (Amy) Chang, San Francisco State University, USA

Mark Landis, San Francisco State University, USA

Shaokun Carol Yu, Northern Illinois University, USA

\begin{abstract}
The current financial crisis has created serious repercussions for accounting education. Public universities have lost funding and initiated huge budget cuts. These drastic cutbacks have resulted in the losses of courses, enrollment, and faculty. These losses will translate into inaccessibility of education will reduce the future accounting work force. To recover from the recession, well trained accountants are critical to provide the financial fundamentals for businesses. While most of us understand that an investment in accounting education is an investment in successful business, effective practices for recruitment are needed in a time of scarce resources. In this paper, we would like to focus on the difficulties occurring in accounting education, which will negatively affect business. Furthermore, we would strongly encourage companies to continuously reach out to potential employees and support accounting education. Some suggestions are provided for cost saving avenues to reduce recruiting costs and develop high quality accounting professionals.
\end{abstract}

Keywords: Accounting profession; Accounting education; CPA firms

\section{INTRODUCTION}

$\mathscr{J}$ ust as Classical Latin was created by ancient scholars and writers, accounting is a fundamental but ultimately artificial language which was specifically developed for the communication of business information. The practice of accounting requires fluency in this language, and for nearly a century, universities have provided students with the basic "language" skills needed for a career in accounting.

The supply chain for accounting practitioners has developed into a symbiotic relationship between universities, accounting firms, and corporations. For decades, accounting firms and corporations have invested money and time to support higher education, and these educational institutions have in turn invested those resources into professors and infrastructure to produce future professionals. In effect, these investments have facilitated the shifting of a significant portion of the expense of training professionals from the firms and corporations to educational institutions which can more efficiently hire experts and capitalize on economies of scale to produce graduates with a relatively standardized set of skills. An accounting degree signifies that a graduate possesses a fundamental understanding of the accounting language; further training that is required of the graduates is often firm- or corporation-specific.

However, recent economic conditions have contracted the flow of donations from firms and corporations to educational institutions. For example, the KPMG foundation has reduced the donations by 7.5 percent. Big 4 internships were cut by 29 percent. In addition, educational institutions that receive government funding have seen extensive cuts in both federal and state funding. These cuts have had, and continue to have, adverse effects on the ability of educational institutions to carry out their missions. In this article, we lay out reasons for accounting firms and corporations to continue funding educational institutions during these difficult economic conditions. 


\section{THE ROLE OF EDUCATIONAL INSTITUTIONS IN THE ACCOUNTING PROFESSION}

The primary mission of the accounting departments at most universities or Schools of Accountancy is to educate students in the mechanics of accounting. Almost all accredited universities require that students attain basic proficiency in intermediate accounting and cost accounting, while additional courses such as accounting information systems, auditing, and taxation are frequently required in many degree programs. Alongside a required accounting curriculum, students are usually offered accounting electives which enable the students to learn more about those areas of accounting that most interest the students.

However, universities can, and often do, modify their curricula to meet the needs of the employers of their graduates. Most commonly, universities that offer master's programs will tailor course offerings to meet the 150 hour requirements of state CPA boards. In many states, these boards require that students complete specific accounting courses such as business ethics before they can sit for the CPA examination, and universities respond by offering those required courses in the curricula.

Some schools allow students to specialize in more specific areas of accounting. For example, schools such as the University of Missouri, the University of Southern California, and Michigan State University have developed specializations in accounting information systems and offer many electives to students interested in studying those areas. A more recent innovation is a certificate in forensic accounting that is being offered at schools such as West Virginia University. Other curriculum modifications are direct responses to specific demand, such as the University of Nevada-Las Vegas' course in auditing in the gaming industry. Yet other schools are able to capitalize on the specific expertise of their professors, such as Rutgers University's accounting class on Machine Learning.

In addition to providing both general and specialized accounting skills, universities offer opportunities for accounting firms and corporations to identify top students, thereby reducing the recruiting burden of those firms and corporations. The most straightforward indicator of a student's ability is the GPA, but unfortunately grade inflation at many universities has reduced variation in this measure thereby devaluing its usefulness. At those universities where substantial variation still exists in GPA, a student's grade point average still may not account for the "soft skills" demanded by the accounting profession, and it does not indicate in which areas of accounting the student is most skilled or interested.

Thus, in addition to GPA, many firms and companies rely on different opportunities available at universities to assess recruits. Student organizations such as Beta Alpha Psi are a particularly useful recruiting tool as recruiters have the opportunity to interact with students potentially over several years. These organizations allow the employers to observe students' soft skills and professional growth while they matriculate. Since students selfselect the organizations to which they belong, the students can signal their specific interests to recruiters, and recruiters can tailor their message to the student group which they are visiting. Groups such as local chapters of the Institute of Internal Auditors, the Institute of Management Accountants, and ISACA are particularly useful for such recruiting opportunities. Other student organizations allow students to network by identity, and these groups can be particularly helpful for firms wishing to promote and support diversity within their companies. Chapters of the Society of Women Accountants, Ascend (supporting Asian students), the National Association of Black Accountants, and ALPFA (supporting Latino students) are excellent examples of these groups. While many accounting firms and companies donate directly to these student organizations, universities still provide significant resources and faculty support for these organizations, and thus universities are helping to facilitate recruiting for accounting firms and companies.

In addition to preparing students for careers in accounting and assisting in recruiting activities, universities also contribute to the accounting profession through their research activities. Faculty research has been instrumental in the development of accounting innovations such as activity based costing, REA, continuous auditing, risk-based auditing, and XBRL. Research also attempts to independently answer questions and verify or refute assumptions surrounding controversial issues in accounting. Questions such as do consulting services impair audit quality, does mandatory partner rotation improve audit quality, does the stock market punish companies whose auditor receives a poor PCAOB inspection report, can the stock market see through accrual manipulations by managers, and does IFRS or U.S. GAAP result in financial statements that are more often manipulated by managers are some of the 
many research questions that academic research has recently been addressing. Research findings such as these provide important factual evidence for debates that can have significant impacts on the accounting profession.

\section{THE EFFECTS OF RECESSION ON EDUCATIONAL INSTITUTIONS AND STUDENTS}

Plunging endowments and reductions in state funding are leading to layoffs, salary freezes, and program cuts (Damast 2009). The recession has created large losses for the federal and state budgets, and subsequent financial funding was slashed for the universities. As a result, substantial budget cuts for the faculty and student body were imposed. To make up for $\$ 813$ million loss in state funding, the University of California announced furloughs, hiring deferrals, and cuts in academic programs in July 2009. At least 41 states have cut assistance to public colleges and universities. Consequently, academic institutions initiated ways to reduce administrative and employee costs. During the academic year of 2009-2010, all of the University of California and California State University schools launched mandated furloughs for all faculty members which equates to a 10 percent monthly reduction in salary and contracts were not renewed for many adjunct professors. Other schools installed hiring freezes, despite vacancies in vital positions, and even more drastic actions such as cutting entire academic programs has been seen. At the Minnesota State University at Mankato, officials cut 28 programs, which resulted in the loss of 80 full-time faculty positions, approximately 13 percent of the faculty. Also, several public universities are actively seeking to reduce enrollment. The University of Florida is aiming to reduce enrollment by 4,000 students by 2012. The California State University system is admitting fewer students despite large increases in the number of applications.

The financial crisis negatively impacts student on several levels. Tuition increases were one of first consequences for the student. By January 2009, the tuition and fees at U.S. four-year public universities had increased 6.5 percent (an average of \$7,020) from the previous school year. There were a few examples of exceptional tuition increases. For instance, the University of California schools increased tuition by 32 percent in 2009. Tuition at all 11 public universities in Florida increased 15 percent for the academic year of 2009-2010. Students on California campuses staged protests against these tuition increases, and they cited particularly negative effects for the working and middle-class students who benefit from state-funded education. To complicate matters, financial support through scholarships and student loans has been drastically reduced. Despite spending more on tuition, students are given less availability to teaching faculty. The class size is expected to increase 10 percent to 20 percent next year. In contrast, faculty and staff positions are expected to decline by at least 10 percent over the next five years at some locations such as the Irvine campus of University of California. At the University of California in Davis, 44 courses and sections are expected to be cut. In 2010, Brandeis University announced cost-cutting proposals to eliminate approximately two dozen faculty positions, and several undergraduate majors and graduate programs. Lastly, entire academic programs have been eliminated. Recently, the senate at Humboldt State University debated the elimination of 14 potential programs including chemistry, computer science, fisheries biology, nursing, philosophy and physics. Clearly, this combination of tuition increases coupled with the loss of teaching faculty and academic programs, is seriously jeopardizing higher education for students. Students are struggled to pay higher tuitions, and they receive reduced access to learning resources and smaller course selections.

The quality of the college experience and training has also been impaired. There are declines in student organizations and their associated social activities. These groups often provide pivotal experiences, skills, and networks. Additional training opportunities such internships furnish critical training for students. Nevertheless, in 2009, accounting firms cut internships to college students across the nation by nearly 21 percent according to the National Association of Colleges and Employers. All of these developments reduce the preparation and capability of individuals needed to rebuild the nation's financial viability and accountability.

\section{THE IMPACT OF THE RECESSION ON RECRUITING FOR ACCOUNTING PROFESSION}

Retaining top talent remains a necessity for CPA firms even in the current economy (Brundage et al. 2010). First, if one assumes that the economy will begin growing again in the relatively near future, accounting firms that lay off staff members and curtail recruiting activities will find themselves short of qualified staff when the economy rebounds. Thus, efforts to salvage current profits (as much as possible) may result in lost future profits as accounting firms may not be able to meet future demand. Instead of suspending recruiting efforts and other 
donations to higher education, some firms have opted to postpone starting dates and lower starting salaries. Recruits have been willing to accept such terms of employment because of the few employment options available. When faced with a difficult set of alternatives, this option is appealing to firms because it allows the firms to continue to hire and develop personnel, save some costs, and still maintain important university ties.

Despite the economic hardships, the recession has created new opportunities for accounting firms. The supply of accounting graduates combined with the reduced demand for graduates allow firms to find the best possible candidates in a larger sea of applicants. As the larger international firms have slowed their recruiting activities, local and regional firms have a prime opportunity to obtain highly qualified and experienced individuals. Finding an excellent accountant can provide the critical analysis and feedback for future growth.

Although firms may have more high quality candidates to choose from at the moment, long-term recruiting difficulties may arise. Accounting is not an inherently attractive profession to college students. A numbers studies over the years have show that a negative stereotypical image of accountants pervades. Unfortunately, the cost of education is increasing for the students as a result of this recession, so the salary differential that exists between other technical fields such as engineering or actuarial sciences and accounting may deflect students away from fields like accounting, particularly given the negative stereotypes of the profession. If the profession loses accounting students, there will be a substantial salary premium that will occur when the accounting services are again in high demand. Therefore, current cost savings in the form of lower salaries and fewer job openings may well result in substantial lost future profits.

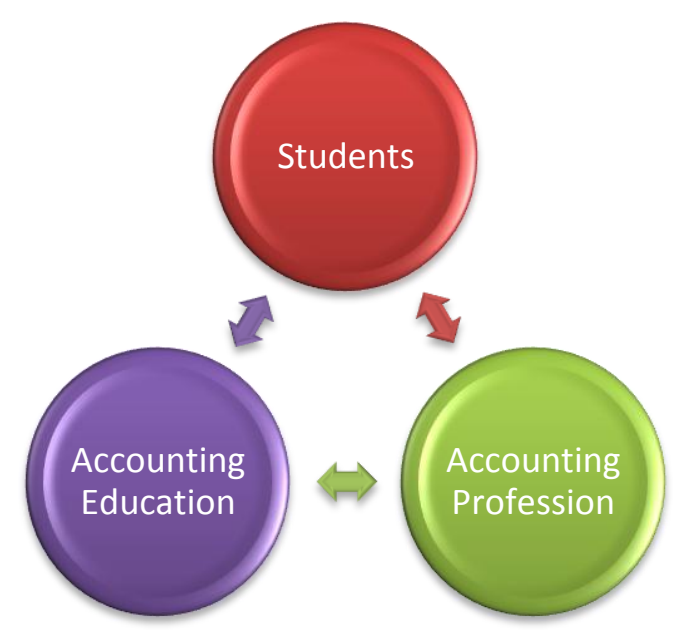

Figure 1: The Interrelationships of Accounting Students, Education and Accounting Professionals

\section{OPPORTUNITIES FOR FIRMS TO INVEST IN EDUCATION}

The relationships among the quality of future workforce, the accounting education, and the accounting profession are pictured in Figure 1. More often than not, the accounting education is the link to connect future workforce and the profession. By understanding the weakening of accounting education due to the economy downturn, and helping to prevent further weakening, the accounting profession can help to strength the relationships among the three.

Firms and companies can maintain their visibility on campus and invest in higher education in a variety of ways during the economic downtown. Direct monetary donations to accounting departments will usually have the most long-term benefit to both universities and firms because the accounting departments will be able to direct those resources to meet immediate needs, avoiding discontinuation of important programs or other operations. The publicity as well as faculty and department goodwill that is generated by these donations often translates to a better perception of the donating firms or companies by the students. This is especially true during the current economic 
downturn as the number of donations is reduced, and the remaining donations have higher visibility.

Another effective direct monetary investment is scholarships. Tuition prices have spiked as universities try to compensate for budget cuts and firms and corporations can assist top students by establishing scholarships either directly through their own offices or through universities. Universities are already equipped to handle the logistics of these donations, so they may be the more efficient choice. Companies and firms can establish specific criteria for their scholarship (e.g., minimum GPA requirements, ethnic or gender qualifications, essays, etc.) and they can work directly with the universities in selecting the recipients of the scholarships. Most accounting departments have scholarship committees composed of faculty members for just this task.

Although shrinking financial support is expected in downturns, other cost-effective programs can also have important influence on students. For instance, rather than eliminating internship programs completely, companies could develop unpaid internships that benefit both student and the firm. These internship experiences provide valuable training for potential employees, and the employer can develop beneficial working relationships.

Another low-cost possibility is a mentoring program which can be beneficial for both students and firms. The student being mentored encounters a wealth of professional experience and knowledge, while the mentor enjoys a fulfilling and important advisory role. Ascend, the student organization supporting Asian students, already actively pursues mentorships for its top members; an opportunity exists for firms and companies to develop similar programs with other student organizations.

Firms and companies can work with universities to develop innovative ways of introducing students to the accounting profession. For example, rather than holding expensive professional meetings at hotels, firms could develop orientation programs on college campuses that are combined with office tours. Likewise, information distribution through email, the Internet (and particularly social and professional networking sites), and text messaging are both practical and economical. Some new forms of telecommunication such as online meetings can provide a more cost-efficient possibility for initiating student-firm relationships.

Finally, employees of firms and companies can donate time instead of money. Many professionals find teaching enjoyable, especially at their alma maters. Unfortunately many universities have reduced adjunct faculty positions, but programs may be developed which can capitalize on the expertise of professionals while maintaining the academic rigor required by universities and accreditation bodies. For example, one urban university is in the beginning stages of developing a corporate tax class coordinated by a faculty member in which a professional teaches a specialized topic for two weeks, and different professionals rotate to teach other topics. Similar programs could be developed in many universities, especially in the more dynamic areas of the profession such as tax law and information technology auditing.

Such involvement can better prepare students for a professional career. Different perceptions of accounting exist between students and professionals, and professional involvement at universities can help bridge the gap. Jones and Abraham (2007) find that practitioners want strong discipline-based skills, strong interpersonal skills, and students to be work-ready, while students tend to focus on work experience and qualification. Kavanagh and Drennan (2008) find the most important skills perceived by students are different from the skills acknowledged by the employers. Jackling and De Lange (2009) find that employers and students have different perceptions in team skills, leadership potential, verbal communication, and interpersonal skills diverge between. De Lange, Jackling and Gut (2006) find that graduates perceive the most important skills to learn are communication and analytical skills.

\section{LOOKING TO THE FUTURE}

The accounting profession is in a transformative state. After centuries of local accounting standards, the profession is entering a world with one set of global standards and encountering new technologies such as object oriented databases and XBRL to store and distribute accounting information. Corporations are demanding continuous auditing, financial institutions are creating complex networks of asset and liability claims, and information ownership is moving to the internet cloud between companies and customers. To adapt, the profession will need to recruit younger, tech-savvy employees who have fluency in accounting principles but are unburdened 
by past practices. Universities will continue to be the first exposure that these eventual recruits have to the profession, and they will continue to teach the language of accounting to future professionals. The involvement and support of the professionals to the universities, even in downtimes such as this, will help ensure that the profession will continue to thrive.

\section{AUTHOR INFORMATION}

Amy Chang is an assistant professor at San Francisco State University. Her research interest is in financial reporting with specific emphasis on issues relating to quality of financial reports, earnings management, earnings quality, and corporate governance.

Mark Landis is an assistant professor at San Francisco State University. His areas of expertise include information systems, group decision making, and auditor decision making.

Carol Yu is a Certified Public Accountant, and she joined Northern Illinois University in 2007. She teaches financial reporting and cost management. Her research interests include corporate governance, earnings management, and segment reporting.

\section{REFERENCES}

1. Brundage H. and M. Koziel. 2010. Retaining Top Talent Still a Requirement for Firms. Journal of Accountancy. May 2010.

2. Damast, A. 2009. Financial Woes Force B-School Cutbacks. Bloomberg Business week. January 2009.

3. De Lange, P., B. Jackling, A. Gut. 2006. Accounting graduates' perceptions of skills emphasis in undergraduate courses: an investigation from two Victorian universities. Accounting and Finance. 46: 365-386.

4. Jackling. B. and P. De Lange. 2009. Do accounting graduates' skills meet the expectations of employers? A matter of convergence or divergence. Accounting Education. 18 (4): 369 - 385.

5. Jones, G. and A. Abraham. 2007. Education implications of the changing role of accountants: Perceptions of practitioners, academics and students. Faculty of Commerce - papers.

6. Kavanagh, M. H. and L. Drennan. 2007. What skills and attributes does an accounting graduate need? Evidence from student perceptions and employer expectations. Accounting \& Finance. 48: 279-300.

7. Employee Retention Guide: How to Keep Your Top Talent on Board. AICPA publication

8. Walker, J. 2010. Firms Invest Big in Career Sites. The Wall Street Journal. June 8, 2010. 